\title{
Pharmacognostical and Phytochemical Evaluation of Leaf of Clerodendrum phlomidis Linn. F.
}

\section{Research Article}

\section{Patel BR ${ }^{1}$, Kavita Kumari ${ }^{2}$, Shreedevi $\mathrm{A}^{3^{*}}$, Shukla VJ ${ }^{4}$, Harisha $\mathrm{CR}^{5}$}

\author{
1. Assistant Professor, 2. PG Scholar, 3. PhD scholar, Department of Dravyaguna, \\ 4. Head, Pharmaceutics laboratory, 5. Head, Pharmacognocy laboratory, \\ Institute for Postgraduate Teaching and Research in Ayurveda, \\ Gujarat Ayurved University, Jamnagar, Gujarat - 361 008. India.
}

\begin{abstract}
Clerodendrum phlomidis Linn.f. is a large bush or small tree belonging to the family Verbenaceae. The present study deals with the pharmacognostical and phytochemical study of leaf including chromatographic evaluation. Clerodendrum phlomidis Linn.f. leaf is rhomboid ovate, acute at apex crenate-dentate at margin, subcordate at base and velvety in texture. Leaf of the plant can be identified microscopically by the presence of hooked trichomes, glandular sessile trichomes, starch grains, oil globules, Anomocytic type of stomata and rhomboidal and prismatic crystal. Preliminary analysis revealed the presence of carbohydrates, steroid, alkaloids, tannin and phenol. HPTLC study of alkaloid showed the presence of two spots in short and three spots in long UV rays. The information generated by this study provides relevant Pharmacognostical and Physico-chemical data needed for proper identification and authentication of leaf of Clerodendrum phlomidis Linn.f.
\end{abstract}

Keywords: Alkaloid, Tannin, Trichome, Oil globule, Starch grain.

\section{Introduction}

Clerodendrum phlomidis Linn.f. is a large bush or small tree, reaching $9 \mathrm{~m}$ high, with more or less pubescent branches. Leaves are 3.8-6.3 by 3.2$3.8 \mathrm{~cm}$, ovate or subrhomboid, obtuse or acute, coarsely crenate-dentate or subentire, undulate, glabrous above, more or less puberulous beneath, base truncate or subcordate. Petiole is $6-20 \mathrm{~mm}$ long. Flower moderate sized, fragrant, in small dichotomous axillary cymes arranged so as to form a rounded terminal panicle. Bracts obovate or lanceolate, acute, leafy. Calyx $1 \mathrm{~cm}$ long or more, divided about half way down, glabrous, not enlarged in fruit. Corolla white or pinkish. Drupe $6 \mathrm{~mm}$ long, broadly obovoid, depressed, the top about level with the points of the persistent calyx-lobes, normally 4lobed with 1 pyrene in each lobe(1). The study is conducted to identify the leaf of plant species with the help of pharmacognostical and phytochemical tests.

\section{Materials and Methods}

Collection and authentication:

For this work, the drug sample i.e leaf of Clerodendrum phlomidis Linn.f. was collected from Jamnagar, Gujarat, after proper identification and authentication through referring various floras and taking advise from taxonomist. Sample was then

*Corresponding Author:

\section{Shreedevi A}

PhD scholar,

Department of Dravyaguna,

IPGT\&RA, Jamnagar

Email: shreedevibbams@,rediffmail.com subjected to various pharmacognostical and phytochemical parameters.

\section{Micromorphological Study}

Collected leaf was observed carefully for their morphological characters and micro measurements were noted. Morphological characters like colour, odour and size were noted down(2).

\section{Microscopic study}

Free hand sections of leaf i.e. petiole, mid-rib, upper and lower epidermis of the research drug was taken and cleared with chloral hydrate. They were first observed in distilled water and then stained with phloroglucinol and Concentrated Hydrochloric Acid. Microphotographs were taken by using Carl Zeiss Trinocular microscope, attached with camera(3). Fine powder was made of these leaves and powder microscopy was carried out of the sample(4).

\section{Micrometric evaluation}

Evaluation of the length and breadth of leaves, trichomes, stomata, prismatic and rhomboidal crystals was done with the help of Carl Zeiss Trinocular microscope attached with camera with preloaded micrometric analysis software(5) and mean value was taken into consideration.

\section{Micro-chemical tests}

Some micro-chemical tests were performed to detect presence of starch grains, crystals and lignified elements(6) in all samples.

\section{(i) Test for starch grains}

Sections and powder were treated with a drop of iodine solution. Starch grains turned blue when examined microscopically. 


\section{(ii) Test for crystals of calcium oxalate}

They are insoluble in glycerine and phenolic reagents but soluble in hydrochloric acid. On adding a drop of hydrochloric acid to the section and powder; calcium oxalate crystals were dissolved and effervescence was seen.

\section{(iii) Test for fibres (Lignified elements)}

Section and powder were treated with phloroglucinol and hydrochloric acid. Sclerenchymatous fibres turned pink in colour.

\section{Chromatographic Analysis}

Chloroform:Methanol $(8.5: 1.5 \mathrm{v} / \mathrm{v})$ was used as solvent system for HPTLC. As per the standard procedure at $256 \mathrm{~nm}$ and $366 \mathrm{~nm}$ analysis was done(7).

\section{Chromatographic Condition}

\begin{tabular}{|c|c|}
\hline Application mode & Camag Linomat V \\
\hline Development Chamber & $\begin{array}{l}\text { Camag Twin trough } \\
\text { Chamber. }\end{array}$ \\
\hline Plates & $\begin{array}{l}\text { Precoated Silica Gel } \\
\text { GF254 Plates. }\end{array}$ \\
\hline Chamber Saturation & $30 \mathrm{~min}$ \\
\hline Development Time & $30 \mathrm{~min}$. \\
\hline Development distance & $8 \mathrm{~cm}$ \\
\hline Scanner & Camag Scanner III. \\
\hline Detection & $\begin{array}{l}\text { Deuterium lamp, Tung } \\
\text { stan Lamp }\end{array}$ \\
\hline Data System & Win cats software. \\
\hline
\end{tabular}

Observations and Results

Table No. 1: External morphology of leaf of Clerodendrum phlomidis Linn.f.

\begin{tabular}{|l|l|}
\hline Parameters & $\begin{array}{l}\text { Clerodendrum phlomidis } \\
\text { Linn.f. }\end{array}$ \\
\hline Colour & Green \\
\hline Size & $8 \times 5 \mathrm{~cm}$ \\
\hline Apex & Acute \\
\hline Shape & Rhomboid ovate \\
\hline Odour & Characteristic \\
\hline Taste & Pungent, bitter and sweet \\
\hline Margin & Crenate-dentate \\
\hline Base & Sub-cordate \\
\hline Texture & Velvety \\
\hline Venation & Reticulate, 4-5 pairs \\
\hline
\end{tabular}

\section{Microscopic characters of Clerodendrum phlomidis Linn.f. leaf \\ Transverse section of petiole}

Diagrammatic sketch showed round to oval shaped section with presence of multicellular warty trichomes which covers the epidermis followed by hypodermis and central ground tissue.

Epidermis was single layered, cuticularised with compactly arranged cells. The epidermal cells had numbers of multicellular warty trichomes, hooked shaped trichomes and sessile glandular trichomes. Two types of sessile trichomes one filled with oil and other multicellular sessile trichomes were present.
Hypodermis was made up of 6-7 layers of collenchyma cells compactly arranged without any air space. Ground tissue was made up of parenchyma cells, some of which were filled with chlorophyll pigments. Parenchyma cells showed presence of prismatic crystals of calcium oxalate and rhomboidal crystals.

Vascular bundles were situated at the centre, having arc shape, open and collateral in arrangement. Phloem was situated beneath xylem and consisted of phloem fibres and sieve elements.

\section{Transverse section through midrib}

Epidermis -In both upper and lower epidermis presence of multicellular warty trichomes, hooked trichomes and glandular sessile trichomes was seen. Some of the epidermal cells were found interrupted by stomatal openings. Epidermis was covered with cuticle. Epidermal cells and trichomes showed presence of colouring matter in them.

Mesophyll- was differentiated into upper palisade and lower spongy parenchyma cells. Palisade parenchyma consisted of 2 layers, while spongy parenchyma consisted of 4-5 layers of parenchyma cells. Between spongy and palisade parenchyma many vascular strands were passing and both layers were filled with oil globules. Vascular bundle showed phloem towards lower epidermis and xylem towards upper epidermis. Phloem was made up of phloem fibers and some sieve plates and xylem consisted of xylem parenchyma and its fibers.

\section{Surface study: Lower epidermis}

Anomocytic type of stomata was present, measuring $0.7 \times 0.4 \mathrm{~mm}, 0.6 \times 0.3 \mathrm{~mm}, 0.6 \times 0.3 \mathrm{~mm}$ at different angles with mean size of $0.6 \times 0.3 \mathrm{~mm}$. Glandular sessile type of trichome was present, with radius of $5 \mathrm{~mm}, 4 \mathrm{~mm}$ and $5 \mathrm{~mm}$, having mean radius of $4.6 \mathrm{~mm}$. Multicellular warty trichomes with 6- celled structure were present. Number of stomata present at different angles was $7,6,8$ respectively in one exposed area. Number of epidermal cells in that area was $36,48,42$. Their ratio i.e. Stomatal Index was observed to be 14.193. Two glandular sessile trichomes were present in per square $\mathrm{mm}$ area.

\section{Upper epidermis}

Greenish chlorophyll pigments were more in upper epidermis as compared to lower epidermis. Anomocytic type of stomata were present measuring $0.9 \times 0.4 \mathrm{~mm}, 0.9 \times 0.3 \mathrm{~mm}, 0.9 \times 0.4 \mathrm{~mm}$ at different angles with mean size of $0.9 \times 0.4 \mathrm{~mm}$. Glandular sessile trichomes with radius of $5 \mathrm{~mm}, 4 \mathrm{~mm}, 5 \mathrm{~mm}$ at various angles with average radius of $5 \mathrm{~mm}$ were present. Number of stomata present at various angles in particular observed area was 5, 5, 6 respectively while number of epidermal cells in that area of observation were 36, 33, 33 respectively. Stomatal Index was found to be 9.7. Only one glandular trichome was present in per square $\mathrm{mm}$ area. Multicellular warty trichomes were also found present. 
Fig. 1 C. phlomidis Linn Plant

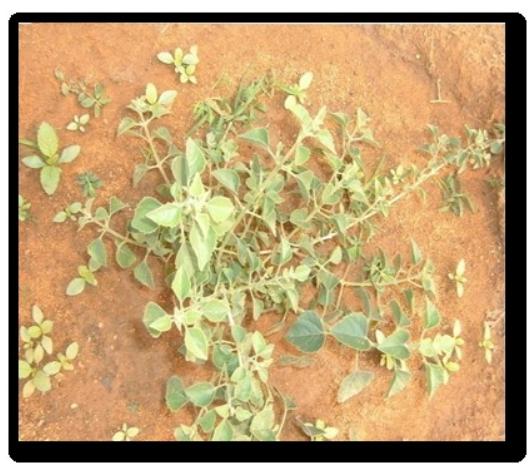

Fig. 4 C. phlomidis Leaf

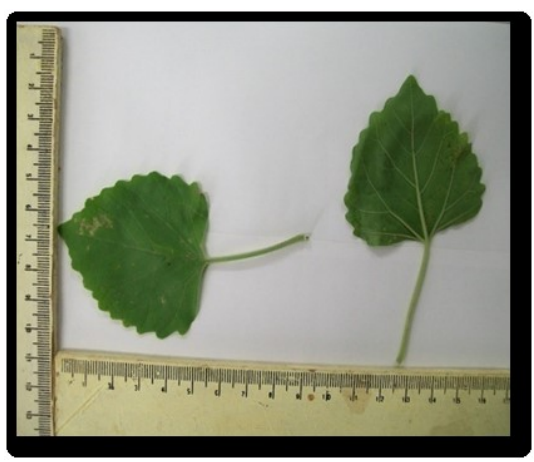

Fig. 7 Warty and hooked Trichome

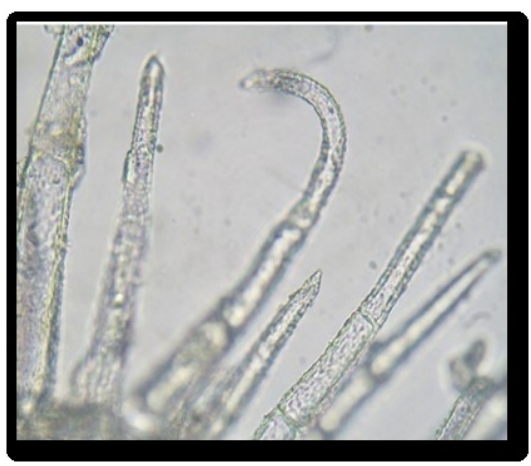

Fig. 10 Oil Globule

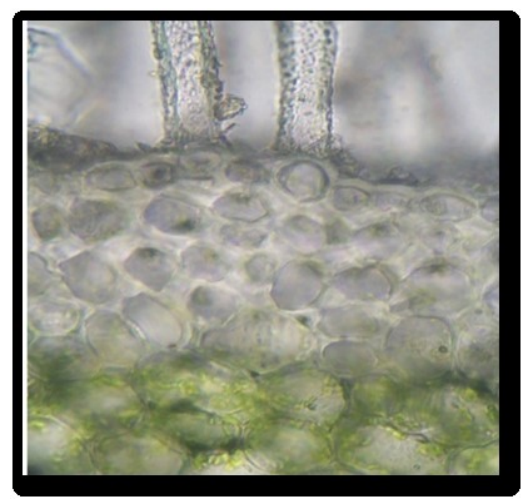

Fig. 2 C. Phlomidis Inflorescence

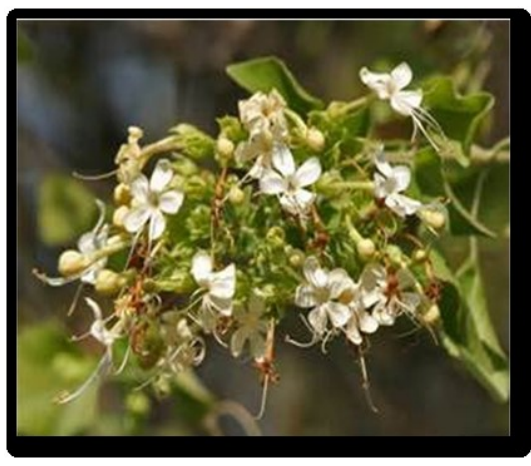

Fig. 5 T S of Petiole

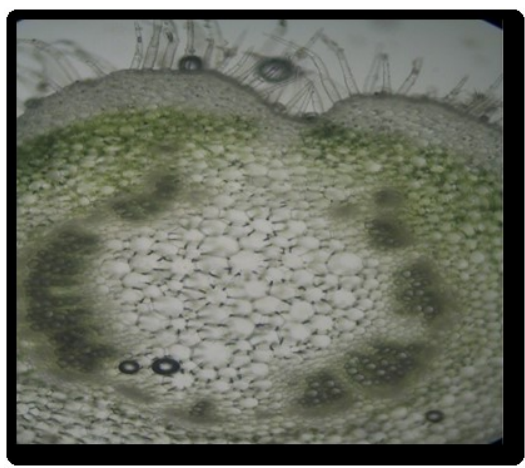

Fig. 8 Rhomboidal Crystal

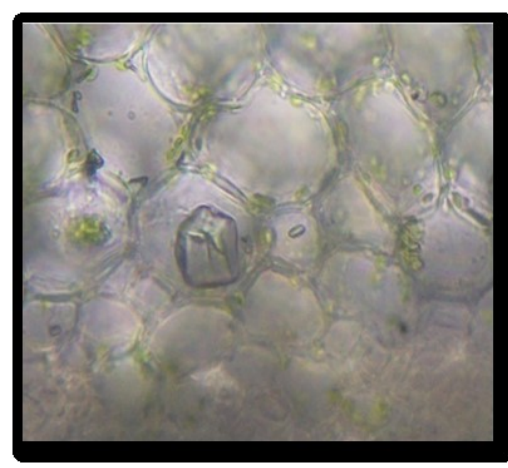

Fig. 11 Anamocytic stomata

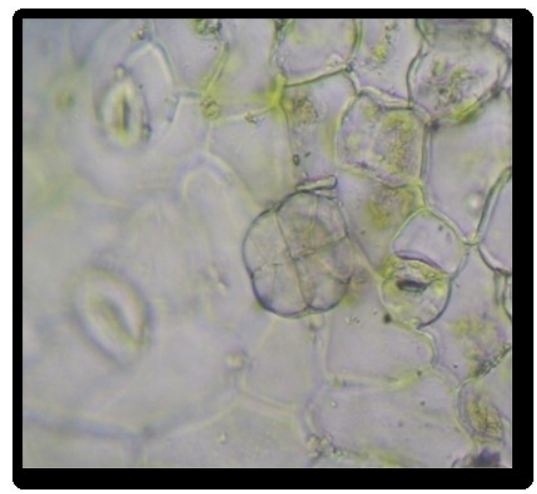

Fig. 3 C. phlomidis Fruit

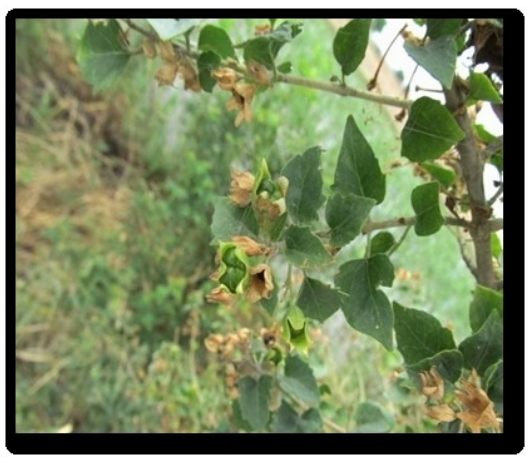

Fig. 6 Bicellular stalked Sessile Trichome

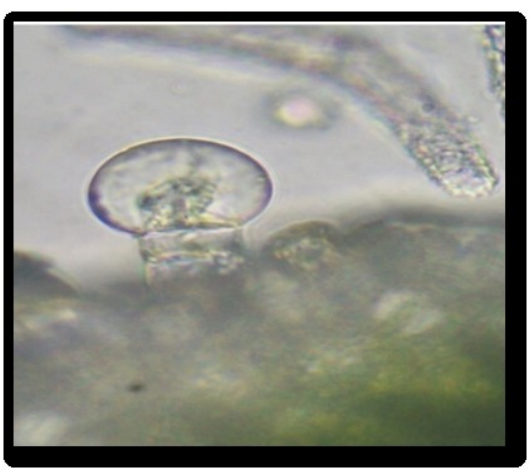

Fig. 9 Vascular Bundle

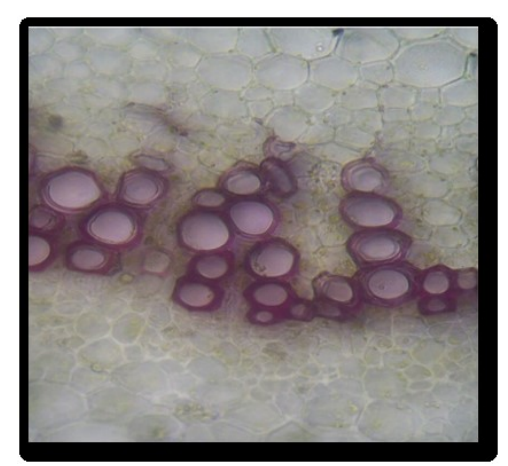

Fig. 12 Leaf TS through mid-rib

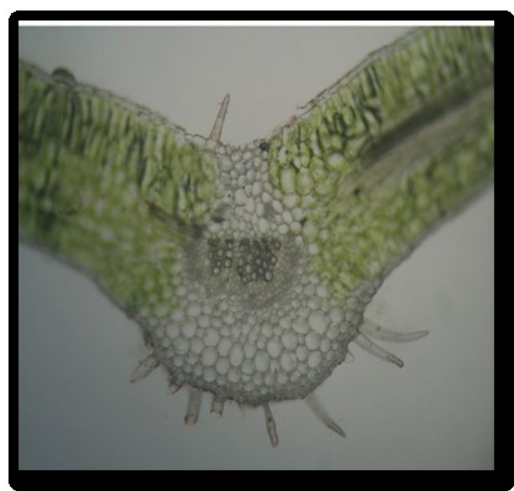


Fig. 13 Coloring matter in Trichome \& Epidermal cells

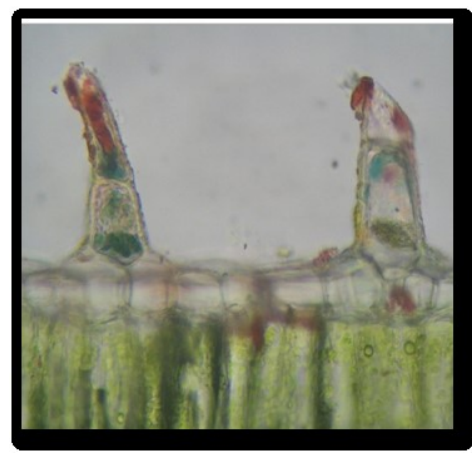

Fig. 16 Brown Content

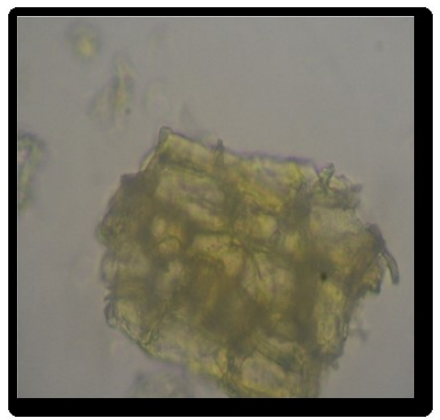

Fig. 19 Fragment of Spiral vessel

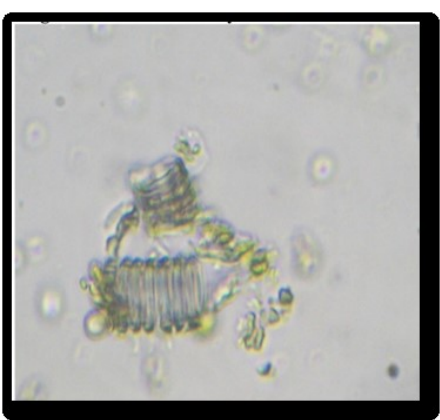

Fig. 14 Sessile Trichome

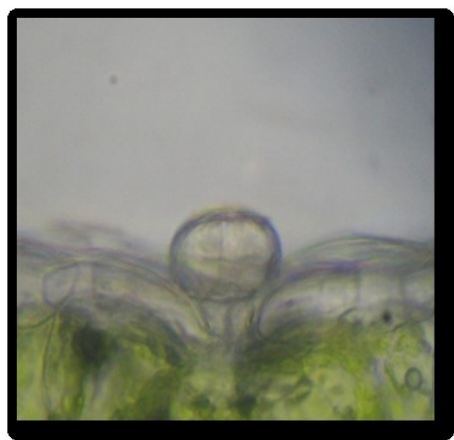

Fig. 17 Vascular Bundle with Xylem \& Phloem

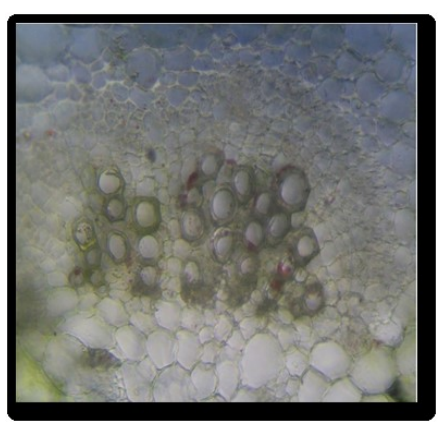

Fig. 20 Prismatic Crystal of calcium oxalate

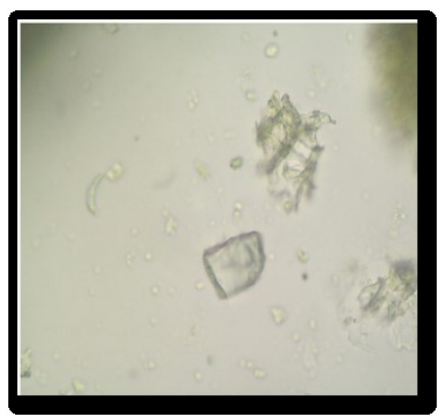

Fig. 15 Mesophyll with Vascular strands

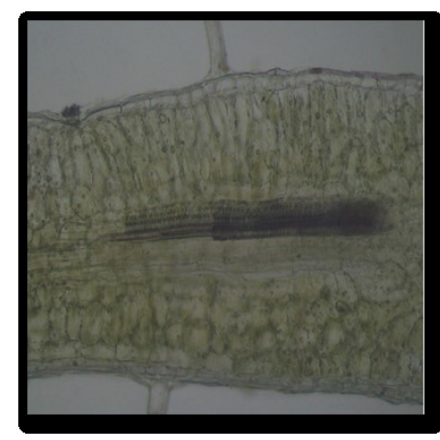

Fig. 18 Powder Microscopy Multicellular warty Trichome

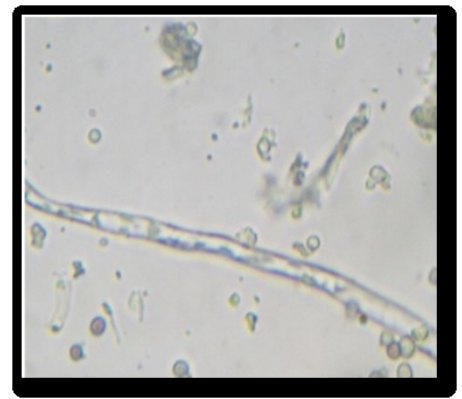

Fig. 21 Fragment of Stomata

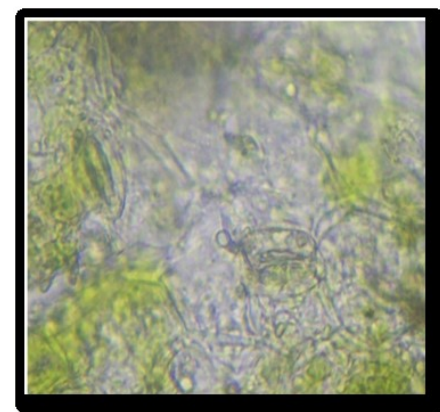

Leaf powder microscopy:

Leaf powder was observed pale green in colour, smooth in touch with characteristic irritant smell and pungentbitter and somewhat sweet taste.

Microscopic examination showed presence of multicellular warty trichome, spongy parenchyma cell, simple fibre, oil globule, spiral vessel, prismatic crystal, brown content, epidermal cell, glandular trichome fragments and presence of rhomboidal crystal fragments in addition.

Table No. 2 Micrometric evaluation of $C$.phlomidis Linn.f. leaf powder

\begin{tabular}{|l|l|l|l|}
\hline S.N & Character & Clerodendrum phlomidis Linn.f. & Measurements \\
\hline 1 & $\begin{array}{l}\text { Crystal - } \\
\text { Rhomboidal } \\
\text { Prismatic }\end{array}$ & Present & $0.4 \times 0.2$ \\
& Present & $0.5 \times 0.3$ \\
\hline 2 & $\begin{array}{l}\text { Trichomes - } \\
\text { Warty }\end{array}$ & Present & $5.5 \times 0.6$ \\
& Multicellular & Present & $3.0 \times 0.6$ \\
& Hook shaped & Present & $1.6 \times 0.3$ \\
& Glandular- oil filled & Present & $1.2 \times 0.3$ \\
& Glandular-multi head & Present & $1.0 \times 0.3$ \\
\hline
\end{tabular}


Shreedevi A et.al., Clerodendrum phlomidis Linn.F. Leaf - Phytopharmacognostical Profile

\begin{tabular}{|l|l|l|l|}
\hline S.N & Character & Clerodendrum phlomidis Linn.f. & Measurements \\
\hline 3 & $\begin{array}{l}\text { Stomata - (fragments) } \\
\text { Anomocytic } \\
\text { Diacytic }\end{array}$ & $\begin{array}{l}\text { Present } \\
\text { Absent }\end{array}$ & $0.6 \times 0.4$ \\
\hline 4 & Fragments of fibre & Present & $8.5 \times 0.2$ \\
\hline 5 & Fragments of spongy parenchyma & Present & - \\
\hline 6 & Fragments of epidermal cells & Present & - \\
\hline 7 & Fragments of annular vessels & Present & - \\
\hline 8 & Oil globules & Present & - \\
\hline 9 & Starch grains & Present & - \\
\hline
\end{tabular}

Table No. 3 Histochemical evaluation of Clerodendrum phlomidis Linn.f. Leaf

\begin{tabular}{|l|l|l|l|}
\hline S. No & Reagent & Observation & Characteristics \\
\hline 1 & Iodine solution-Starch & $\begin{array}{l}\text { Macroscopic- it become blackish } \\
\text { Microscopic- found round shape particles }\end{array}$ & + \\
\hline 2 & Ferric chloride-Tannin & Samples become blackish & + \\
\hline 3 & HCl-Calcium & It produced bubbles & + \\
\hline 4 & HCl-Lignin & Lignified elements become red in colour & + \\
\hline 5 & Sudan III solution-Oil globules & It becomes red in colour & + \\
\hline
\end{tabular}

Table No. 4 Phytochemical evaluation of Clerodendrum phlomidis Linn.f.

\begin{tabular}{|c|c|c|}
\hline Sr No & Tests & C.phlomidis Leaf \\
\hline 1. & \multicolumn{2}{|l|}{ Proteins } \\
\hline a. & Biuret test & $-\mathrm{ve}$ \\
\hline b. & Ninhydrin test & $-\mathrm{ve}$ \\
\hline 2. & \multicolumn{2}{|l|}{ Carbohydrate test for starch } \\
\hline a. & Iodine test & $+\mathrm{ve}$ \\
\hline b. & Fehling's test & $+\mathrm{ve}$ \\
\hline c. & Benedict's test & $-\mathrm{ve}$ \\
\hline d. & Test for non reducing sugar such as sucrose & $-\mathrm{ve}$ \\
\hline 3. & \multicolumn{2}{|l|}{ Tannins } \\
\hline a. & Gelatin test & $+\mathrm{ve}$ \\
\hline 4. & \multicolumn{2}{|l|}{ Anthocyanins } \\
\hline a. & Aqueous $\mathrm{NaOH}$ test & $+\mathrm{ve}$ \\
\hline b. & Conc. $\mathrm{H}_{2} \mathrm{SO}_{4}$ test & $-\mathrm{ve}$ \\
\hline 5. & \multicolumn{2}{|l|}{ Glycosides } \\
\hline a. & Molisch's test & $+\mathrm{ve}$ \\
\hline b. & Conc. $\mathrm{H}_{2} \mathrm{SO}_{4}$ test & $+\mathrm{ve}$ \\
\hline 6. & \multicolumn{2}{|l|}{ Saponin } \\
\hline a. & Foam test & -ve \\
\hline 7. & \multicolumn{2}{|l|}{ Flavonoids } \\
\hline a. & Flavonoid test & $-\mathrm{ve}$ \\
\hline b. & Shinoda test & $-\mathrm{ve}$ \\
\hline c. & Conc. $\mathrm{H}_{2} \mathrm{SO}_{4}$ test & $+\mathrm{ve}$ \\
\hline 8. & \multicolumn{2}{|l|}{ Phenols } \\
\hline a. & Phenol test & $+\mathrm{ve}$ \\
\hline 9. & \multicolumn{2}{|l|}{ Steroids } \\
\hline a. & Salkowski's test & $+\mathrm{ve}$ \\
\hline 10 & \multicolumn{2}{|l|}{ Alkaloids } \\
\hline a. & Dragendorff's test & $+\mathrm{ve}$ \\
\hline
\end{tabular}


Table No:5 HPTLC of Leaf of Clerodendrum phlomidis Linn.f. at 254nm and 366nm

\begin{tabular}{|c|c|c|c|c|c|}
\hline \multirow[t]{2}{*}{ Samples } & \multirow{2}{*}{$\begin{array}{l}\text { Solvent } \\
\text { System } \\
(\mathrm{V} / \mathrm{V})\end{array}$} & \multicolumn{2}{|c|}{ Short UV 254 nm } & \multicolumn{2}{|c|}{ Long UV 366 nm } \\
\hline & & No. of spots & Rf value & No. of spots & Rf value \\
\hline $\begin{array}{l}\text { Clerodendrum } \\
\text { phlomidis } \\
\text { Linn.f. }\end{array}$ & $\begin{array}{l}\text { Chloroform : Methanol } \\
(8.5: 1.5 \mathrm{v} / \mathrm{v})\end{array}$ & 2 & $\begin{array}{l}0.03 \\
0.90\end{array}$ & 3 & $\begin{array}{l}0.03 \\
0.86 \\
0.91\end{array}$ \\
\hline
\end{tabular}

Fig. 22 Densitogram of $C$. phlomidis at $254 \mathrm{~nm}$

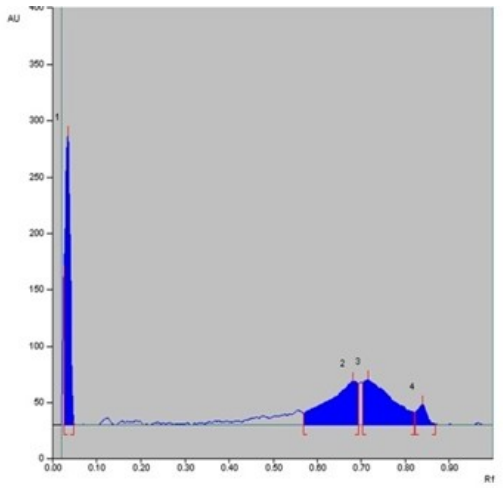

\section{Conclusion}

Pharmacognostical findings i.e. glandular sessile trichomes, starch grains, oil globules, Anomocytic type of stomata and rhomboidal and prismatic crystal were important characters to identify the leaf of Clerodendrum phlomidis Linn.f. Phytochemical evaluation of leaf of Clerodendrum phlomidis Linn.f. showed presence of starch, tannin, phenol and alkaloid. Thus with the help of pharmacognostical and phytochemical tests the leaf of Clerodendrum phlomidis Linn.f.was identified.

\section{References}

1. Kirtikar KR; Basu BD (1989), Indian Medicinal Plants, Published by Lalit Mohan Basu, Allahabad, India, 2nd Edition. vol. III. p. 1947

2. Wiliam Charles Evans(2009), Trease and Evans. 1996, Pharmacognosy. London: W.B. Sunders Company Ltd. 16th ed. 569-570.
Fig. 23 Densitogram of $C$. phlomidis at 366nm

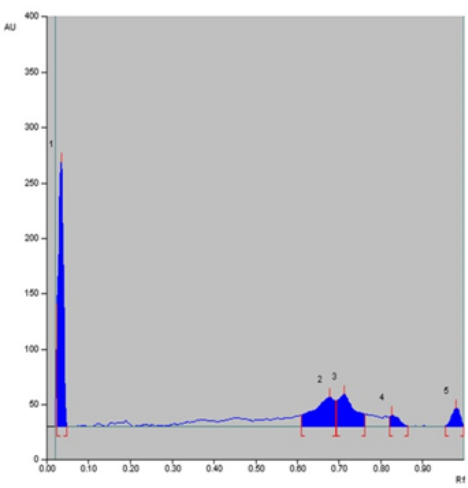

3. Khandelwal K R (2008), Practical pharmacognosy: Techniques and Experiments; Ed 19, Nirali Prakashan; Pp 15-18.

4. Krishnamurty KV, Methods in the plant histochemistry, Vishwanadhan Pvt Limited, Madras. 1988: $1-70$

5. Anonymous (2001), The Ayurvedic Pharmacopoeia of India, $1^{\text {st }}$ edi.,Govt. of India, Ministry of Health and Family Welfare, Dept. of Indian Systems of Medicine \& Homeopathy, New Delhi. Part - I, Appendix -3 .

6. Anonymous, (1999), The Ayurvedic Pharmacopoeia of India, Vol 1, Appendix 2, $1^{\text {st }}$ Edition, Govt Of India, Ministry of Health and Family welfare, Department of ISM \& H, New Delhi.

7. Anonymous, Planner Chromatography, Modern Thin Layer Chromatography, Switzerland, 1999. 